\title{
Liability Implications of the Rotterdam Rules for Indian Dry Ports
}

\author{
Girish Gujar* $^{*}$ Sik Kwan Tai ${ }^{* *} \cdot$ Adolf K.Y. Ng ${ }^{* * * * *}$
}

\begin{abstract}
The carrier's liability during the sea leg of transportation is quite unambiguous. However, the shipper's concerns during the land leg remain yet to be adequately addressed. In India, the land leg of container transportation between gateway ports and dry ports is conducted by the road/rail transporters appointed by the carrier or the dry port operators. The inland transportation of containers, however, is governed by different legal instruments, the provisions of which are not congruent, especially with regard to the liabilities and responsibilities of the dry port operator against the carrier. Understanding such deficiency, this paper attempts to ascertain the implications of ratifying the Rotterdam Rules for India's existing maritime law regime, especially those applicable to dry ports. We examine the maritime law regimes of different countries which are already signatories to the Rotterdam Rules and apply a similar reasoning in the Indian context. We conclude that one of the effects of ratification by India would be the reduction of ambiguities concerning the liabilities of dry port operators, being now considered a maritime performing party. Consequently, dry port operators would now be held responsible for container security and thus would be perforce to exercise due diligence in discharging its duties as a custodian of the cargoes in its charge. In addition to the efficiency gains that such development would bring about, it would be beneficial for the evolution of an appropriate container security policy for the Indian dry ports sector.
\end{abstract}

Key words : Rotterdam rules, dry ports, container security policy, India

\footnotetext{
* Professor, School of Management, D.Y. Patil University, Mumbai, India, girish.gujar@dypatil.edu

** Professor, Division of Business and Management, Beijing Normal University-Hong Kong Baptist University United International College, Zhuhai, China, adolfng@uic.edu.cn

*** Senior Fellow, St. John's College, University of Manitoba, Winnipeg, MB, Canada, adolf.ng@umanitoba.ca
} 


\section{Introduction}

The establishment of an integrated door-to-door transportation system plays key roles in providing seamless movement of cargoes. In India, inland transportation is part of the door-to-door supply chains, and the handling of containers is mostly carried out by the various dry port operators which do so by using one or more mode (s) of transportation. Broadly speaking, dry ports act as critical nodes along global supply chains, where their primary purpose is to consolidate and distribute cargoes while simultaneously acting as intermodal transportation exchanges. Dry port operations can be broadly divided under three categories: (1) container yard operations, for the storage of empty and laden containers; (2) freight station operations regarding storage, stuffing and stripping of containers; and (3) transportation of empty and laden containers by rail, road or both between dry and gateway ports (Notteboom and Rodrigue, 2005).

Earlier in India, inland transportation and the handling of containers were covered by different legal regimes depending on the transportation mode. The provisions of these regimes were not entirely congruent, resulting in the creation of ambiguities as regards to the contractual relationship between dry port operator and the carrier who issues the bill of lading for the entire door-to-door transportation service (Schmitthoff, 1986). In this case, imagine a chemical shipment from a factory in New Delhi to a warehouse in Munich (both located far away from gateway ports) covered by a through bill of lading issued by the carrier (e.g., shipping line). According to the Indian Carriage of Goods by Sea Act of 1925 (COGSA) and its subsequent amendments, the carrier is expected to exercise due diligence in protecting the cargoes and its prompt dispatch until the destination (Paul, 2005). However, according to Section 46A of India's Railway Act (1989), under which the cargoes are stuffed and moved during the inland leg of the journey by the dry port operator, the latter cannot be held responsible for not exercising due diligence, nor it is responsible for any delays in delivering the cargoes (Mukherjee et al., 2009). In this case, the limitation of liability, amounts between 50 and 200 Indian Rupees per kg stated under the different Acts, varies sharply (Hariharan, 2001).

Subsequently, in addition to COGSA, India enacted the Multimodal Transportation of Goods (MMTG) Act in 1993. This was loosely based on several international maritime conventions, such as the Contract for Carriage of Goods by Road of 1956 (C.M.R. Convention), and the International Carriage of Goods by Rail 1980 (C.O.T.I.F). However, the MMTG Act is not widely used as it does not cover the activities of sub-contractors who are the actual performing parties (Haralambides and Behrens, 2000). For instance, at present, the shipper has a contractual relationship with the carrier (bill of lading), governed by COGSA. The latter subsequently enters into a separate contractual relationship with the dry port operator evidenced by an Inland Way Bill (IWB) governed by the Indian Railways Act 1989 (IRA). However, the Act itself is silent on the responsibilities and liabilities 
of the dry port operator vis-à-vis the carrier (Raghuram, 2007).

Thus, the simultaneous application of different legal regimes to different contractual relationships between the various parties involved in the inland transportation of cargoes leads to the creation of ambiguities as regards to the responsibilities and liabilities especially of the dry port operator (Haralambides and Gujar, 2011). Furthermore, internationally recognized transport documents, such as the FIATA Bill of Lading and COMBICON, are not recognized by the Indian government. In addition, the Multi-modal Transport Document (MTD) issued under the MMTG Act is often not accepted by foreign banks, causing inconvenience for shippers, carriers, multimodal transportation operators, and consignees.

To address such issues, the Rotterdam Rules were drafted by the United Nations Commission on International Trade Law (UNCITRAL), adopted by the UN, and opened for signature in 2008 and 2009, respectively. A salient new feature of the Rotterdam Rules is the introduction of the performing party concept. Article 1 (6) defines performing party as an entity that performs, or undertakes to perform, any of the carrier's responsibilities under a contract of carriage, and acts (directly or indirectly) at the carrier's request or under the carrier's supervision or control. Based on this, a dry port can be considered as a performing party under a contract of carriage, such as a bill of lading (Syam Kumar, 2009).

This definition is broader than the performing carrier used in previous international conventions, such as the TCM Draft, MT Convention, and the ICC Uniform Rules (Brooks, 2000). Moreover, the Rotterdam Rules provide for liability, specifically for a maritime performing party and not for all performing parties. Article 1 (7) defines a maritime performing party ${ }^{1}$ as one that offers services related to sea carriage. By nature of its functions, we argue that a dry port operator is a maritime performing party and is thus liable to the carrier for any loss/damage of cargoes while in its custody (Sturley, 1995). The ratification of the Rotterdam Rules by India would not only facilitate the establishment of appropriate contractual relationships between the carrier and other performing parties, such as dry ports, but also promote the establishment of a proper regulatory framework governing dry ports throughout the country.

In fact, the entire transportation process is governed by multiple laws, some of which are civil in nature while some of them are administrative. The objectives and purposes of every such law are different. As such, it is impossible for a single research paper to cover the entire gamut of laws governing the entire transportation process, nor is this paper attempting to do so. In this regard, the paper focuses on the simple counterfactual, i.e., ratification of the Rotterdam Rules and its probable impacts on container security. We purposely ignore other probable impacts of ratification of the Rotterdam Rules as they are beyond the purview of this study.

125 countries have signed the Rotterdam Rules as signatories. By the time when this study took place, five countries (Benin, Cameroon, Spain, Togo, and Republic of the Congo) have ratified the Rules. For further details, see United Nations Treaty Collections (https://treaties.un.org/Pages/ViewDetails.aspx?src=IND\&mtdsg_no=XI-D$8 \&$ chapter $=11 \&$ clang=_en). 


\section{Contextual Setting of Dry Ports and Their Responsibilities and Liabilities}

The Ministry of Commerce of the Indian government, was tasked in 1992 with the primary objective of facilitating international trade by way of encouraging the establishment of dry ports. The ministry was thus the competent authority licensing the setting up of dry ports. However, the ministry guidelines that specify the establishment and functions of dry ports are silent when it comes to the law that should apply to dry port operations. In fact, the guidelines do state that dry ports should broadly fall under the overall control of the local Customs Commissioner, although they fail to give the details its powers and duties (Customs India, 1998). Thus, the mechanism for reviewing the dry port's (considered as a custodian of the cargoes in its charge) conduct and performance is delegated to the local custom commissioner. As such, the ministry, which initially licensed the applicant for setting up a dry port, does not play any further roles in dry port operations (Bagchi and Virum, 1996).

According to the Indian Customs Act of 1962, the jurisdictional Commissioner of Customs is the competent authority for the approval of a physical place as customs area, and for the approval/appointment of a custodian (in this case, a dry port operator) under Sections 8 and 45, respectively. Section 16 of the General Clauses Act of 1897 (Law Commission of India, 2005) stipulates those powers vested with an authority, for any appointment, include the power to suspend or dismiss the person so appointed. Hence, the Commissioner of Customs has also the authority to de-notify or take away a custodianship in the case of non-compliance to the principles of natural justice (Customs Circular F.No.450/ 105/2008-Cus.IV, dated 25 th July 2008). Nowadays, dry port operations, including container transportation, involve numerous key federal and regional stakeholders, such as customs, railways, police, and similar enforcement and inspection agencies. The onus of conducting the day-to-day operations of dry ports lies with the custodian (Annexure-II: Setting up of ICDs/CFSs, Customs Manual, 2006-07). As the custodian, the dry port operator is responsible for the safety and security of the cargoes stored in its area. Also, the Commissioner of Customs is empowered to review the approval granted before the expiry of the initial period and may order a review before the completion of the approval period.

Also, in discharging its duties and responsibilities towards the Customs Commissioner, the dry port operator needs to exercise due diligence to ensure the safety and security of cargoes while in its custody. To adequately do so, it needs to undertake the precautionary steps to ensure the safety and integrity of cargoes in the port, equipment, and personnel need to be allotted (or at least prescribed), and cargoes handling procedures be stipulated. Nevertheless, often, this is not the case 
(Heaver, 2002). There are no prescribed yardsticks or benchmarks for dry ports to observe, or for the customs to request. There have been attempts to fill such a gap through assigning the supervision of dry ports to the Commissioner of Customs.

The first dry port in India was established by the Container Corporation of India (CONCOR), a state-owned enterprise under India's Ministry of Railways. The Indian government authorized CONCOR to issue the CONCOR IWB, in lieu of a Railway Receipt (RR), and to quote and collect all charges directly from the customer (Indian Railway Commercial Manual, Volume 2, Para 1476, ISO Containers services). In 2007, container rail transportation was opened to the private sector. Nowadays, there are 16 Container Train Operators (CTOs), including the state-owned CONCOR that also issue IWBs.

The IWB constitutes prima facie evidence of receipt of cargoes by the dry port operator from the carrier, in apparent good order and condition, except as otherwise noted with respect to damage sustained by the cargo before arriving at the dry port. The IWB is issued by the dry port operators for the containers to be carried by it, and it must be given up at destination, by the consignee, at the time of taking delivery. It is issued subject to the conditions and liabilities as specified in the Railways Act. According to the terms stated in the Railways Act, the carrier must accept responsibility for all particulars furnished in respect of cargoes tendered by it for stuffing containers and carriage to the gateway port by the dry port operator. It goes on to state that the carrier is deemed to have indemnified the dry port operator against any damage or loss suffered by it by reason of incorrect particulars provided by him regarding the cargoes.

Hence, the dry port treats the carrier as a consignor and enters a contractual relationship with it to handle and transport containerized cargoes to and from gateway ports. The dry port does not recognize the shipper with whom the carrier has its own contractual relationship. Because of this, the shipper cannot move against the dry port operator for any loss/damage to its goods while they are in the custody of the dry port. Furthermore, according to the IWB issued by the dry port operator to the carrier, the contractual relationship between them is governed by the Indian Railways Act. Accordingly, the dryf port operator does not automatically indemnify the carrier regarding any liabilities and responsibilities the latter may have accepted vis-à-vis the shipper. Hopefully, such circumstance is going to change once the dry port operator is considered a maritime performance party.

Regarding the liability of the shipper/carrier for erroneous declaration of containerized goods, it is critical to understand the mens rea of the stakeholder and the liability due to its act of erroneous declaration. Perhaps considering the potential of damages caused by the liability in question, the time has arrived to look beyond the co-relationship coefficients between the freight earned and the compensation payable. This argument indicates a necessity for re-visiting the limitation clauses in the various sea transportation legislation. Eventually, it may force the carrier to discharge/exercise its due diligence responsibilities more effectively. 


\section{The Rotterdam Rules and the Concept of Performing Party}

The current legal regime governing the transportation of cargoes by sea is burdened by the co-existence of three different maritime conventions: The Hague Rules; the Hague-Visby Rules; and the Hamburg Rules. In addition, several hybrid versions of these exist. This situation has led to numerous legal ambiguities. Under the current regime shippers and carriers do not have the benefit of a binding and balanced universal instrument in support of contracts of carriage involving various modes of transportation. To rectify this, the Comite Maritime International (CMI) and the UNCITRAL have formulated a unified set of rules (Myburgh, 2000). The final product has resulted in a Convention, known as the United Nations Convention on Contracts for International Carriage of Goods Wholly or Partly by Sea, commonly referred as the Rotterdam Rules.

The main purpose of the Rotterdam Rules is to rectify the contractual imbalance regarding the responsibilities and liabilities of the shipper on the one hand, and of the carrier on the other. To understand the complexity, we need to appreciate that, due to intense cross holdings of different interests across international borders, it often becomes onerous to segregate the interests of the shipper, the carrier, banks, and consignees. For instance, due to the proliferation of open registries, the shipowner is seldom the citizen of the (trading) flag state (Raja, 2007). The same can be said of cargo interests. In practice, open registries have made irrelevant the original characteristics of the nations who were signatories to the Hague-Visby or Hamburg Rules (Sturley, 1995). In this case, the Rotterdam Rules address topics not covered by other international instruments on the carriage of goods, including matters pertaining to the rights of controlling party, transfer of rights, jurisdiction, and arbitration. Also, it spells out the parties liable and responsible for the transportation of cargoes. The comprehensive coverage provides a transparent and detailed account of maritime trade information. This is bound to boost the confidence of trading parties and hence spur more trade (Goddard, 2010). Furthermore, it offers a higher weight-based limitation of liability of three Special Drawing Rights (SDRs) per kg of cargoes, representing a substantial increase over the current US\$500 per package limitation provided for under COGSA. Finally, it imposes liability on carriers for delay in delivery, provided the time of delivery has been agreed upon in the contract of carriage.

Also, the Rotterdam Rules recognize that shippers, rather than carriers, are better-suited to identify certain types of serious risk, such as shipments that involve hazardous cargoes. In such cases, the Rotterdam Rules require shippers to share information regarding the hazardous nature of cargoes and impose liability on shippers that contravene this requirement. More importantly, it provides the employees 
of the carrier, agents, and independent contractors with the same rights and obligations as those enjoyed by the carrier, as long as they are deemed as maritime performing parties (Thomas, 2009). In this case, the rapid rise of container shipping and the appearance of Non-Vessel-Operating Common Carriers (NVOCCs) serve as the major reasons behind the concept of performing party. Unlike the present definition of a performing party in the Rotterdam Rules, the draft provision on the performing party made expressed reference only to 'handling, custody, or storage of the goods', without reference to 'carriage'. The modified texts of the Rotterdam Rules suggest that the concept of a performing party has a much wider scope than what was initially conceived.

The concept of performing party is mainly defined in Articlel 6 of the Rotterdam Rules as follows:

"Performing party" means a person other than the carrier that performs or undertakes to perform any of the carrier's obligations under a contract of carriage with respect to the receipt, loading, handling, stowage, carriage, care, unloading or delivery of the goods, to the extent that such a person acts, either directly or indirectly, at the carrier's request or under the carrier's supervision or control.

A "performing party" does not include any person that is retained, directly or indirectly, by a shipper, by a documentary shipper, by the controlling party, or by the consignee instead of by the carrier.

Accordingly, a performing party can be understood from different perspectives, as follows:

It must not be a carrier which, as defined in Article 1, means a person who enters a contract of carriage with the shipper. This definition must be read in the light of Article 1, which also defines the contract of carriage as a contract in which a carrier, against the payment of freight, undertakes to carry goods from one place to another. The contract shall provide for carriage by sea and may provide for carriage by other modes of transport in addition to the sea carriage. From these provisions, and for the purpose of determining a performing party, a carrier may be under a carriage contract, wholly or partly by sea. An international carriage contract involving no sea leg is thus excluded from the ambit of the Rotterdam Rules.

The performing party must carry out some of the carrier's responsibilities under the contract of carriage. This means that there is a need to establish the expectation that the party is performing what the carrier is obliged to do under the contract of carriage.

The performing party must act or perform either directly or indirectly, at the carrier's request or under the carrier's supervision or control. This implies that a connection must exist between the two to establish whether a party is the 
performing party for the purposes of the Rotterdam Rules. If it can be argued that a party engages in acts which are not requested, supervised, or controlled by the carrier, the party is not a performing party for the purposes of the Rules.

The connection between the performing party and the ocean carrier is both essential and exclusive, in terms of establishing the party's position under the Rotterdam Rules.

As per point (4), the following entities cannot be perceived as a performing party in the spirit of the Rotterdam Rules, even though they may perform some acts like what the performing party would normally undertake:

A party retained by the shipper (defined in Article 1 paragraph 8 as a person that enters a contract of carriage with a carrier).

The documentary shipper (defined in Article 1 paragraph 9 as a person, other than the shipper, that accepts to be named as shipper in the transport document or electronic transport record).

The consignee, who directly appoints a party to undertake to perform a part of the contract (defined in Article 1 paragraph 13 as the person that -pursuant to Article 51- is entitled to exercise the right of control).

Thus, the performing party is a carefully defined concept with a specific role in a carriage contract covered by the Rotterdam Rules. This includes the obligation to receive goods at a point convenient to the shipper, carry the goods to the port of departure, or from the port of destination, by appropriate means, load them onto a vessel, properly handle, store, and care for them during carriage (whether the goods are on board or in a warehouse), carry them safely in compliance with the carriage contract, unload them at the port of destination, and deliver them safely at the point agreed in the carriage contract. While the legal liability of container carriers, or NVOCCs, often extends beyond the port-to-port segment of a carriage contract, they are not fully protected against loss or damage to cargoes while at the custody of the dry port. This is also problematic for the shipper who often faces unexpected legal difficulties, concerning whom to sue and how, in case of loss or damage to cargoes. A benefit of the concept of performing party is in its attempt to address such difficulties, arising from current shipping practices.

A maritime performing party is an entity that performs, or undertakes to perform, any of a carrier's obligations, from the arrival of the goods at the port of loading to their departure from the port of discharge. This means that a maritime performing party must first be a performing party and one which performs or undertakes to perform the carrier's obligations only in the port-to-port segment of a carriage. Due to the contractual relationship between the performing party and the maritime performing party, the liability of both must be jointly read and assessed. This means that a reference to the performing party, undertaking carrier obligations in the port-to-port leg, must also be read in reference to the maritime performing 
party, carrying out similar tasks. For instance, a port authority which loads/unloads cargoes, or a rail/road transportation company that transports the cargoes between the gateway ports and dry ports, or a dry port which offers temporary storage to the cargo before being transported to the destination.

However, in the Rotterdam Rules, a performing party, or a maritime performing party, is frequently and interchangeably mentioned in concurrence with the carrier, in the provisions concerning receipt, handling, carrying, loading, or unloading and delivery of cargo. As such, either party could assume the same liability to the cargo interests, such as the shipper. In brief, the carrier is liable for the breach of its obligations caused by the acts or omissions of any performing party under the contract of carriage, to the extent that the person acts either directly or indirectly at the carrier's request or under the carrier's supervision or control. This arrangement is logical in the sense that the carrier is the one who enters the carriage contract with the shipper or other cargo interests.

\section{Implications of Dry Port as a Performing Party}

As mentioned, the dry port operator issues an IWB to the carrier as evidence of a contract of inland carriage. This IWB goes on to state that the inland contract of carriage is subject to the Indian Railways Act 1989. However, the Act is silent about dry port operations and its contractual relationships with the carrier. This aspect creates uncertainties and ambiguities especially in the absence of adequate case laws, legal judgments, and precedents. In this case, the IWB further goes on to state that the carrier is deemed to have indemnified the dry port operator about liabilities arising from mis-declaration of cargoes. Prima facie, this clause appears to be incomplete, especially as it does not define 'mis-declaration of cargoes' and 'limitation of liability'. Thus, the legality of the contractual relationship between the carrier and the dry port operator appears to be vague and improperly defined. Therefore, one of the key implications of India's ratification of the Rotterdam Rules would be the possibility of a dry port operator to being considered a maritime performing party. This could result in the elimination of ambiguities regarding the contractual relationship between the carrier and the dry port operator (Bichou et al., 2014). Also, as a maritime performing party, the dry port operator would be considered responsible and liable, to the same extent as the carrier, for the goods in his custody, although it has no direct relationship with the shipper. By issuing the IWB, the dry port operator would be deemed to have indemnified the carrier for claims brought against him by the shipper in respect of loss or damage suffered by the goods while in the custody of the dry port operator. Nowadays, dry ports assume a pivotal position in global supply chains. A significant number of cargoes is stuffed/de-stuffed at dry ports rather than at the gateway seaports. Thus, the importance of container security at dry ports needs to be looked at carefully. 
For several reasons, this issue, does not get the attention it deserves and, as a result, over a period, it has evolved into the weak link of the supply chain.

Security at dry ports has been entrusted by the customs to the Customs Cargo Service Providers (CCSPs), or dry ports which act as custodians of cargoes. The customs have prescribed in detail the infrastructure the custodian is required to provide at the dry port (Handling of Cargo in Customs Areas Regulations, 2009. No. 26/2009 - Customs (N.T.), dated 17 March 2009) (e.g., adequate parking space for vehicles, boundary walls, internal roads for service and circulating areas, electronic weighbridge, gate complex). The violation of the guidelines may attract severe penalties and the Commissioner of Customs can even revoke the custodian's license in case of persistent violations. In this case, it is pertinent to note that the customs guidelines do not mention electronic surveillance, such as installation of Close Circuit Television Systems (CCTV), for recording the activities at the dry port gate complex or inside the warehouse/yards. Moreover, the examination of exported goods is supposed to be done by the customs and not by the custodian. However, cargo inspections do not contribute to increase security, as their primary aim is, apparently, to prevent revenue leakage rather than to ensure container security. Indeed, the Customs Act states without ambiguity that the examination of goods is a customs function. However, the responsibility of cargo security in a dry port is with the custodian which does not have a suitable container security policy in place. As a result, inadequate personnel, together with increasing throughputs, serves to widen the crucial container security gap.

\section{Discussion}

Cargo safety and security in dry port involves numerous key stakeholders, such as customs, railways, and police, in addition to local law enforcement, investigation and inspection/survey agencies. The onus of providing security in the dry ports has been placed on the custodian. In this instance the dry port is the custodian. However, the custodian is not saddled with the responsibility of exercising due diligence to ensure non carriage and stuffing of contraband in containers. Due diligence indicates the measures undertaken and the procedures adopted to ensure security and integrity of cargo in the dry port (Gujar et al., 2018).

The Indian Railways Act was drafted in an era when Indian Railways (IR) were not transporting containers. It has yet to develop a system of container cargo inspections and continues to rely on the expressly stated threat in the Railways Act that makes the consignor (carrier) liable for any damage or loss suffered by it blaming incorrect particulars, furnished by the consignor regarding the cargo, in the forwarding note submitted by it to the dry port operator. It is interesting to note that, hitherto, all the agencies involved in stuffing, loading, and transportation of 
containers hold the consignor liable for the particulars and do not consider checking the correctness as part of their responsibilities, even when they are expected to carry out due diligence in such matters.

Although, dry port operators issue their own IWBs for the goods received by them for transportation, there is no standardized format for the IWBs. However, all formats of the IWBs implicitly state that "This Inland Way Bill is issued subject to the conditions and liabilities as specified in the Railways Act 1989." Also, it is mentioned in all the IWBs that the claims for loss suffered while transporting containers by road are settled as per Carriage by Road Act 2007. Thus, the provisions of the Railways Act are invoked only for the railway portion of the transportation which further complicates the issue of responsibility from the perspective of the shipper. It is obvious that there is an inherent contradiction between the stated legal status on the IWB and the legal obligations arising out of the Railways Act under which road transportation is undertaken.

Apart from the advantages listed above, ratification of the Rotterdam Rules would help in the identification of precise risks carried by the specific stakeholders at the time where failure of container security is breached. It would also increase the transparency of the entire transportation process. Furthermore, it would assist in the enforcement of due diligence responsibility of the carrier strictly. Next, it would help in the reduction of ambiguity in identification of risk holder jurisdiction. In addition, it would assist in apportioning of the blame for the container security risk failure and share of compensation payable. Most importantly, it would clarify as to who should prosecute the shipper for misinformation provided if any. Finally, it would help in resolving the legal implications for resolving the legal implications.

As regards to compromising the integrity of the container, it is obvious that the breach of container security results in the vessel becoming unseaworthy. But the consignee becomes aware of this factor only after the container reaches its destination and is de-stuffed, i.e., after the voyage is complete. As such, it is rather fruitless to terminate the contract of carriage. Ironically, in several cases, the consignees have refused to accept the consignment due to the contents not matching with the description in the manifest and thus terminating the contract of carriage. Apart from the above, there are some additional advantages, such as it has the potential to reduce misuse of the unknown clause by carrier as provided for by the Hague-Visby Rules. It is widely known that in several cases the shippers are essentially subsidizing the empty container repositioning costs of carrier, hence carriers are not keen in prosecuting them for erroneous information provided by them. In the absence of the Rotterdam Rules, different modes of inland transporters are governed by different laws and different procedures too. This might help in standardization of such issues. Such a situation creates confusion, delay, and the culprit escapes responsibility and somebody suffers injustice without redress. Finally, the Hague-Visby Rules are silent about third party liability and associated risks are inadequately covered. 


\section{Conclusion}

Although India enacted the MMTG Act in 1993 to provide a seamless legal environment for the entire inland transportation of international containerized cargo, it failed to achieve the stated objective for several reasons. One of the most important reasons was the non-recognition of the MMTG Act by foreign nations. Another reason for the failure to gain wider acceptability was its inability to appropriately integrate the different legal provisions mentioned in the different Acts which governed the inland transportation process, especially in regard to the liabilities and responsibilities of the various performing parties, including dry ports. Hence, we argue that the ratification of the Rotterdam Rules by India could bring much needed clarity regarding responsibilities and liabilities of the dry port operator, especially in exercising due diligence while conducting stuffing operations at the dry port.

\section{References}

Annexure-II: Setting Up of ICDs/CFSs, Customs Manual, 2006-07.

Bagchi, P. and Virum, H. (1996) European Logistic Alliances: A Management Model. The International Journal of Logistics Management 7(1):93-108.

Bichou, K., Szyliowicz, J. S., and Zamparini, L. (2014) Maritime Transport Security: Issues, Challenges and National Policies. Cheltenham: Edward Elgar.

Brooks, M. R. (2000) Sea Change in Liner Shipping: Regulation and Managerial Decisionmaking in a Global Industry. Amsterdam: Pergamon.

CONCOR's Official Website. Title. Retrieved from http://www.concorindia.com (Last accessed in January 2021).

Customs Manual. (1998) Customs Manual: Setting up of ICDs/CFSs. Retrieved from http://www.customsindiaonline.com/content.php?id=manual23

Law Commission of India (2005). Law Commission of India. Retrieved from http:// lawcommissionofindia.nic.in/51-100/Report60.pdf

Customs Circular. F.No.450/105/2008-Cus.IV, 25 Jul 2008. Goddard, K. S. (2010) The Application of the Rotterdam Rules. The Journal of International Maritime Law 16(3):210-220.

Gujar, G., Ng, A. K. Y., and Yang, Z. (2018) Contemporary Container Security. Champaign: 
Palgrave Macmillan.

Haralambides, H. E. and Behrens, R. (2000) Port Restructuring in a Global Economy: An Indian Perspective. International Journal of Transport Economics 27(1):19-39.

Haralambides, H. and Gujar, G. (2011) On Balancing Supply Chain Efficiency and Environmental Impacts: An eco-DEA Model Applied to the Dry Port Sector of India. Maritime Economics and Logistics 14(1):122-137.

Hariharan, K. V. (2001) Containerization and Multimodal Transport in India. Mumbai: Shroff Publications.

Heaver, T. D. (2002) The Evolving Roles of Shipping Lines in International Logistics. International Journal of Maritime Economics 4(3):210-230.

Indian Railway Commercial Manual, Volume 2, Para 1476, ISO Containers Services.

Mukherjee, P. K. and Basu, A. B. (2009) Legal and Economic Analysis of Service Contracts under Rotterdam Rules. Malmo: World Maritime University.

Myburgh, P. (2000) Uniformity or Unilateralism in the Law of Carriage of Goods by Sea. Victoria University of Wellington Law Review 31:255-383.

Notteboom, T. E. and Rodrigue, J. P. (2005) Port Regionalization: Towards a New Phase in Port Development. Maritime Policy \& Management 32(3):297-313.

Paul, J. (2005) India and the Global Container Ports. Maritime Economics \& Logistics 7(2):189-192.

Raghuram, G. (2007) Working Papers on Turnaround of Multimodal Transport in India. Ahmadabad: Indian Institute of Management.

Schmitthoff, C. M. (1986) The Law and Practice of International Trade. London: Steven's and Sons. pp 455-458.

Raja, S. (2007) Multimodal Transportation of Goods Act, 1993: A Critical Appreciation. Student Advocacy 7, 66.

Sturley, M. F. (1995) Uniformity in the Law Governing the Carriage of Goods by Sea. Journal of Maritime Law and Commerce 26, 553.

Syam Kumar, V. M. (2009) Reflections on Multimodal Transport Operator's Liability for Delay in Delivery. Kochi: National University for Advanced Legal Studies.

Thomas, D. R. (2009) A New Convention for Carriage of Goods by Sea: The Rotterdam Rules. Oxford, UK: Lawtex. pp. 89-110. 